\title{
Pembinaan Model Pendidikan Pembangunan Lestari untuk Program Pengajian Sarjana Muda Pendidikan Teknologi Maklumat di Universiti Pendidikan Sultan Idris
}

\section{Construction of Sustainable Development Education Model for Bachelor of Information Technology Education Program at Sultan Idris University Education}

\author{
Lim Chen Kim ${ }^{1 *}$, Haufiku Martin Shafiihuna ${ }^{2}$, Wang Shir $\mathrm{Li}^{3}$ \\ ${ }^{1}$ Institute for Environment \& Development (LESTARI), Universiti Kebangsaan Malaysia; kim@ukm.edu.my \\ ${ }^{2}$ Department of Computing, Universiti Pendidikan Sultan Idris; haufikum@gmail.com \\ ${ }^{3}$ Department of Computing, Universiti Pendidikan Sultan Idris; shirli_wang@fskik.upsi.edu.my \\ * Correspondence author
}

To cite this article (APA): Kim, L.C., Shafiihuna, H.M., \& Li, W.S. (2021). Pembinaan Model Pendidikan Pembangunan Lestari untuk Program Pengajian Sarjana Muda Pendidikan Teknologi Maklumat di Universiti Pendidikan Sultan Idris. Journal of ICT in Education, 8(2), 126-143. https://doi.org/10.37134/jictie.vol8.2.12.2021

To link to this article: https://doi.org/10.37134/jictie.vol8.2.12.2021

\begin{abstract}
Abstrak
Artikel ini membincangkan pembinaan model pendidikan pembangunan lestari (SD) bagi program pengajian Sarjana Muda Pendidikan (Teknologi Maklumat) di UPSI. Pembinaan model pendidikan SD ini menggunakan dua jenis integrasi pendidikan SD iaitu integrasi mendatar dan integrasi menegak melalui pendekatan yang menjadikan SD sebagai satu kursus merentasi displin dalam usaha memperkenalkannya ke dalam program yang ada. Pendekatan pedagogi yang digunakan dalam pendidikan SD adalah konstruktism yang berkonsepkan pembelajaran melalui perlakuan beserta kaedah pembelajaran berasaskan masalah. Bagi pendekatan organisasi pula, pembinaan model pendidikan SD menggunakan kaedah gabungan antara pendekatan atas-bawah dengan pendekatan bawah-atas untuk menjadikan sistem pengurusan program pengajian pendidikan SD dapat berkembang secara sistematik. Pembinaan model pendidikan SD adalah berdasarkan proses mengenalpasti komponen, mengenalpasti kompetensi, menyatakan kompetensi, menganalisis kurikulum, mengintegrasi kurikulum dan menilai model. Akhirnya, satu model pendidikan SD bagi program pengajian Sarjana Muda Pendidikan (Teknologi Maklumat) terbentuk dan ianya telah memberikan gambaran jelas mengenai semua aspek yang diperlukan untuk mengintegrasikan model tersebut ke dalam kurikulum.
\end{abstract}

Kata Kunci: pembangunan lestari (SD), kecekapan tenaga, program Pendidikan Teknologi Maklumat 


\begin{abstract}
This article discusses the construction of a sustainable development (SD) education model for the Bachelor of Education (Information Technology) program at UPSI. The construction of this model uses two types of integration, namely horizontal integration and vertical integration through an approach that makes SD as a course across disciplines in an effort to introduce it into existing programs. The pedagogical approach used in SD education is constructism with the concept of learning by doing along with problem-based learning method. As for the organizational approach, the construction of the SD education model uses a combination of a top-down approach with a bottom-up approach to make the management system of SD education programs grow systematically. The construction of the SD education model is based on the process of identifying components, identifying competencies, addressing competencies, analyzing the curriculum, integrating the curriculum and evaluating the model. Finally, a model of SD education for the Bachelor of Education (Information Technology) program was formed and it has provided a clear picture of all the aspects needed to integrate the model into the curriculum.
\end{abstract}

Keywords: sustainable development (SD), energy efficiency, information technology education program

\title{
PENGENALAN
}

Walaupun terdapat banyak literatur mengenai pendidikan pembangunan lestari (Sustainable Development @SD), masih ada bidang utama yang perlu menjadi perhatian terutama dalam penyatuan SD yang lebih baik ke dalam kurikulum, penyelidikan, dan yang paling penting penyatuan SD secara holistik ke dalam sistem pendidikan di institusi pengajian tinggi (IPT) (Hess \& Collins, 2018; Ramos et al., 2015). Kebanyakan IPT telah dan sedang membuat kemajuan dalam pelaksanaan SD namun proses menyatukan SD ke dalam kurikulum dalam konteks lokal dan global di IPT adalah satu cabaran yang sering dihadapi oleh banyak pihak. Menurut Wals (2014), antara cabaran yang dihadapi adalah budaya universiti, kurikulum yang bersifat statik dan kegagalan menangani perubahan. Namun, wujud keperluan untuk menghasilkan dan menggubal kurikulum yang lebih banyak kurikulum yang berpusat SD dalam memastikan kurikulum yang dibangunkan dapat memupuk kesedaran pelajar ke arah kelestarian guna tenaga secara cekap dan berkesan.

Di Malaysia, pendidikan SD sangat penting dalam membantu masyarakat dalam mendidik komuniti dan lokaliti dalam menggunakan sumber tenaga secara optima. Ini sesuai dengan hasrat kerajaan dalam membantu ke arah penjimatan penggunaan bahan api seperti arang batu, minyak dan gas (CETREE, 2021). Salah satu usaha dalam memastikan hasrat ini dapat direalisasikan adalah melalui perancangan program pendidikan termasuklah latihan dan kesedaran masyarakat tentang kepentingan pendidikan SD. Misalnya, satu pusat penyelidikan yang wujud di Universiti Sains Malaysia (USM) turut menumpukan aspek pendidikan SD di Malaysia. Pusat Pendidikan, Latihan dan Penyelidikan Tenaga DiPerbaharui (TD) dan Kecekapan Tenaga (KT) CETREE, USM berperanan dalam meningkatkan kesedaran masyarakat Malaysia tentang kecekapan tenaga sebagai satu usaha menambah nilai dan ciri-ciri sosial komuniti yang positif. 
Sebagai satu permulaan, program pengajian Sarjana Muda Pendidikan (Teknologi Maklumat) dipercayai sesuai untuk menerapkan pendidikan SD dan pendidikan EE disebabkan pelajar-pelajar yang didaftarkan ke dalam program ini adalah pelajar baru di universiti yang ingin mendalami dalam bidang pendidikan dengan penggunaan Teknologi Maklumat. Ciri-ciri sosial yang positif ini dipercayai mampu untuk dijadikan sebagai usaha dalam memupuk komuniti di Malaysia dalam mengaplikasikan amalan kecekapan tenaga dalam kehidupan seharian mereka. Pendidikan kecekapan tenaga (Energy Efficiency @ EE) juga adalah penting dalam memastikan penggunaan sumber tenaga dapat dimanfaatkan oleh masyarakat dengan kadar yang minima (Symaco \& Tee, 2019; Klimova \& Rondeau, 2017). Ini perlu bagi memastikan penggunaan bahan api (misalnya seperti minyak, gas dan arang batu) dapat digunakan secara optimum dalam masyarakat Malaysia. Kadar penggunaan bahan api ini dikatakan semakin berkurangan dan bekalannya semakin susut dari semasa ke semasa (Purvis, Mao \& Robertson, 2019). Justeru, pendidikan SD dan pendidikan EE diperlukan sebagai suatu inisiatif baharu atau mekanisma sokongan bagi persediaan, perancangan dan pelaksanaan pendidikan SD dan pendidikan EE dari pelbagai pihak.

\section{PENYATAAN MASALAH}

Terdapat jurang dalam literatur dalam bidang pendidikan SD dan pendidikan EE. Selain dari bilangan rujukan yang sedikit dalam bidang berkenaan, terdapat sebilangan contoh model untuk program Sarjana Muda terutama dalam bidang Teknologi Maklumat berkaitan dengan pendidikan SD dan pendidikan EE. Cadangan kaedah penerapan pendidikan SD dan pendidikan EE di peringkat Sarjana Muda seharusnya menjadi suatu kemestian semasa proses penggubalan program pengajian berkenaan (Paletta et al., 2019; Casarejos et al., 2017; Torre et al., 2017). Saranan ini berpandukan bahawa permintaan pendidikan EE sedia ada di institusi pengajian tinggi agak kurang (Leal Filho et al., 2019).

Malah pandangan yang mengatakan pendidikan masa kini di abad ke-21 memerlukan penggabungan teknologi terkini dengan penerapan pendidikan SD dan pendidikan EE (Alahari, Issa, \& Nau, 2019; Ciriminna et al., 2016). Menurut Desha et al. (2015), pendidikan SD dan pendidikan EE sangat penting kerana ada keperluan untuk perancangan jangka panjang untuk pendidikan SD dan pendidikan EE di peringkat pengajian tinggi, dalam sektor kerajaan dan sektor industri. Ini kerana topik yang terlibat pendidikan SD dan pendidikan EE adalah diperlukan dan akan terus berkembang dengan kepelbagaian pengetahuan dan kemahiran baharu untuk disepadukan dalam kurikulum.

Jelas bahawa pendidikan SD dan pendidikan EE adalah penting dalam semua bidang pendidikan terutamanya bagi program yang berkaitan dengan teknologi masa hadapan untuk membantu pelajar memahami pemerolehan pengetahuan dan kemahiran dalam pendidikan SD dan pendidikan EE yang diperlukan oleh masyarakat untuk usaha untuk membentuk masa hadapan yang lebih lestari. Oleh itu, tujuan utama artikel ini adalah untuk membincangkan kajian dalam pembinaan model untuk pendidikan SD dan pendidikan EE bagi program Sarjana Muda berteraskan Teknologi Maklumat. Kebanyakan program Sarjana Muda berteraskan Teknologi Maklumat di UPSI tidak menerapkan kedua-dua pendidikan SD dan pendidikan EE setelah merujuk kepada PROFORMA ataupun 
Rancangan Infrastruktur (RI) kecuali subjek yang berkiatan dengan matematik kejuruteraan, pengaturcaraan berorientasikan objek dan rangkaian yang menerapkan salah satu jenis pendidikan sama ada SD atau EE. Oleh itu, ia adalah sesuai untuk menjadi satu kajian kes tentang penerapan pendidikan SD dan pendidikan EE dalam program Sarjana Muda.

\section{PENDIDIKAN SD}

Seksyen ini menjelaskan maklumat latar belakang mengenai aspek-aspek utama yang diperlukan untuk kejayaan integrasi pendidikan SD dalam kurikulum program Sarjana Muda berteraskan Teknologi Maklumat.

\section{Pemegang Taruh}

Staniškis dan Katiliūtè (2016) menyatakan pendidikan SD tidak boleh terbatas pada kaedah pengajaran dan pembelajaran atau kandungan kurikulum. Pendidikan SD juga tidak dapat dikembangkan dalam individu malah perlu bergantung kepada integrasi pelbagai bidang dengan penglibatan pihak berkepentingan atau pemegang taruh dalam usaha pengembangan kurikulum itu sendiri. Pemegang taruh dalam konteks pendidikan SD merangkumi semua pihak yang berperanan dalam mengajar dan mendidik masyarakat (dalam konteks persekitaran sebenar yang turut dikenali sebagai "living lab" @ makmal kehidupan) berkaitan dengan pendidikan SD untuk generasi akan datang (Adam, Martin, \& Boom, 2018). Terdapat beberapa kategori pemegang taruh yang terlibat dalam pendidikan SD.

Dalam kajian ini, terdapat empat kumpulan pemegang taruh utama (Hossain et al., 2019) yang terlibat iaitu:

i. Pemboleh (enablers): Organisasi (awam, pemodal, atau organisasi bukan kerajaan, perbandaran, dan organisasi pembangunan wilayah) yang menyokong aktiviti dalam makmal kehidupan dengan mempromosikannya serta memperuntukkan sokongan kewangan atau ruang untuk aktiviti dalam makmal kehidupan dilaksanakan.

ii. Penyedia (providers): IPT yang membawa pengetahuan dan kepakaran serta aktiviti sokongan inovasi dalam pendidikan SD termasuklah kurikulum, pelaksanaan pengajaran, penilaian dan pentaksiran.

iii. Pengguna (users): Pelajar dan fakulti yang mengambil bahagian dalam makmal kehidupan dengan memainkan pelbagai peranan dalam pendidikan SD.

iv. Pemakai (utilizers): Organisasi awam atau swasta yang dapat memanfaatkan hasil aktiviti inovasi dengan pelbagai cara.

\section{Makmal Kehidupan (Living Lab)}

Adalah penting bagi pelajar untuk menggunakan persekitaran semula jadi, sosial dan binaan, termasuk institusi mereka sendiri, sebagai konteks dan sumber pembelajaran (UNESCO, 2015). 
Menurut Hossain et al. (2019), makmal kehidupan menekankan kesinambungan melalui pembelajaran dan pengembangan berterusan. Kumpulan pemegang taruh dalam makmal kehidupan perlu memikul tanggungjawab yang besar untuk kesan ekonomi, sosial dan persekitaran. Selain itu, makmal kehidupan juga memberi tumpuan terutamanya pada produk dan perkhidmatan yang lestari. Untuk mendapatkan pemahaman yang lebih komprehensif mengenai kelestarian dan mengembangkan penyelesaian masa hadapan, pendekatan makmal kehidupan yang menyusun penyertaan pengguna dalam persekitaran eksperimen dunia nyata dicadangkan dalam kajian ini.

Memperkenalkan strategi kolaboratif seperti makmal kehidupan boleh menggalakkan pelaksanaan dan integrasi pendidikan SD dalam program pengajian di IPT (Tejador et al., 2018; Jahn et al., 2013). Atas sebab itu, makmal kehidupan mampu menyokong pengembangan kompetensi yang sesuai dalam kalangan pelajar (Bürgener \& Barth, 2018) serta mempunyai kesan penting terhadap peralihan ke arah masyarakat yang lebih lestari (Akins et al., 2019; Masseck, 2017). Lebih-lebih lagi, pelajar dapat memperolehi manfaat daripada adanya infrastruktur Teknologi Maklumat yang maju serta bersifat kolaboratif dalam makmal kehidupan (Raoufi et al., 2019; Flammini et al., 2018).

\section{Bangunan Hijau}

Bangunan hijau merupakan suatu bangunan yang mempunyai reka bentuk, struktur pembinaan atau pengoperasiannya dapat mengurangkan kesan negatif akibat pemasalahan iklim dan menimbulkan kesan positif terhadap iklim dan persekitaran semula jadi (Sahakian \& Seyfang, 2018). Ada juga yang menggunakan takrifan bangunan pintar yang merujuk kepada struktur dan pengoperasian bangunan yang menggunakan proses automatik bagi pengawalan operasi bangunan secara automatik termasuklah pemanasan, pengudaraan, penyaman udara, pencahayaan, keselamatan dan sistem lain.

Bangunan hijau yang pintar boleh dirujuk sebagai makmal kehidupan dalam pendidikan SD kerana bangunan hijau menggunakan kepelbagaian disiplin ilmu untuk menyelesaikan masalah-masalah tertentu (Trechsel et al., 2018). Misalnya dalam kajian ini, bangunan hijau digunakan sebagai alat bantu pengajaran dan pembelajaran bagi kurikulum berasaskan Teknologi Maklumat seperti sistem komputer dan rangkaian komputer. Penting untuk diperhatikan bahawa penggunaan bangunan hijau dapat diperluaskan kerana makmal kehidupan mampu memberi pengetahuan dan kemahiran kepada pelajar berkaitan dengan pendidikan SD dan pendidikan EE terutamanya bagi topik kecekapan tenaga dan sumber tenaga serta tidam terbatas pada bangunan pintar, grid pintar dan sistem pengurusan tenaga rumah sahaja (Washington-Ottombre, Washington, \& Newman, 2018, Robertson et al., 2018; Nowotny et al., 2018; Li et al., 2018; Pattinson, 2017).

\section{Grid Pintar dan Sistem Pengurusan Tenaga Rumah (HEMS)}

Salah satu kelebihan grid pintar ialah membolehkan penghantaran elektrik lebih cekap (Nishimura \& Malheiros, 2018). Grid pintar merujuk kepada grid elektrik, rangkaian saluran penghantaran, pencawang, transformer (alat yang mengubah voltan arus ulang alik) dan banyak lagi yang menghantar elektrik dari loji kuasa ke rumah atau bangunan. Nižetić et al. (2019) menyatakan 
bahawa memahami prosedur berkaitan dengan kecekapan tenaga dalam rumah atau bangunan adalah pengetahuan ke arah kelestarian kehidupan. Secara amnya, dngan mengetahui pendidikan EE permintaan tenaga dapat dikurangkan dan seterusnya mampu menghasilkan pekerjaan yang lestari.

Terdapat banyak alat yang digunakan untuk kecekapan tenaga yang lebih baik dan Sistem Pengurusan Tenaga Rumah (Home Energy Management System @ HEMS). Zhou et al. (2016) menyatakan bahawa HEMS adalah sistem rumah yang penting yang memantau dan mengatur pelbagai peralatan rumah dalam masa nyata, berdasarkan pilihan pengguna melalui antara muka mesin-manusia, untuk menjimatkan kos elektrik dan meningkatkan kecekapan penggunaan tenaga. Selanjutnya, Nilsson et al. (2018) menyatakan bahawa HEMS dapat memberikan maklum balas tenaga serta boleh menyebabkan peningkatan kesedaran mengenai penggunaan tenaga dan penjimatan tenaga sekitar 5 peratus hingga 15 peratus. Romanach et al. (2017) menyatakan kecekapan tenaga rumah masa kini sangat bergantung kepada penggunaan alatan teknologi yang mempunyai status dan keupayaan dalam penggunaan tenaga yang cekap.

\section{Pendekatan Integrasi Disiplin}

Terdapat dua jenis utama integrasi pendidikan SD ke dalam kurikulum di IPT (Sidiropoulos, 2014). Pertama, integrasi mendatar (horizontal) yang berlaku apabila konsep pendidikan SD terjalin ke dalam kursus yang ada secara individu di seluruh kurikulum. Kedua, integrasi menegak (vertical) yang berlaku apabila pendidikan SD diwujudkan sebagai satu kursus yang khusus dalam kurikulum berkenaan. Kedua-dua jenis integrasi pendidikan SD ke dalam kurikulum program Sarjana Muda Pendidikan Teknologi Maklumat telah digunakan dalam kajian ini.

Pelbagai pendekatan untuk mengintegrasikan pendidikan SD ke dalam kurikulum program Sarjana Muda. Namun ada lima pendekatan utama yang muncul dalam literatur pendidikan SD. Menurut Sidiropoulos (2018), lima pendekatan ini iaitu:

i. memasukkan elemen SD sebagai tambahan topik dalam kursus yang terpilih dalam program berkenaan;

ii. menjadikan SD sebagai satu kursus merentasi displin dalam usaha memperkenalkannya ke dalam program yang ada;

iii. menjadikan prinsip kelestarian sebagai subjek atau kursus teras bagi program berkenaan;

iv. menawarkan SD sebagai pengkhususan dalam program pengajian yang ada; dan,

v. menawarkan SD sebagai satu program pengajian yang khusus.

Berdasarkan lima pendekatan ini, kajian ini menumpukan kepada pendekatan merentasi disiplin yang disatukan secara mendatar yang mana ketiga-tiga tonggak iaitu ekonomi, sosial dan persekitaran diajar melalui penyampaian yang cukup seimbang. Figueiro dan Raufflet (2015) menyatakan bahawa 
pendekatan merentasi disiplin adalah pendekatan yang mengasingkan integrasi merentas kurikulum melalui tugas atau aktiviti tertentu. Menurut Lozano dan Lozano (2014) pula, jalinan SD lebih tertumpu kepada idea di dalam kursus bagi menawarkan peluang yang lebih menonjol bagi pelajar Sarjana Muda untuk mengasimilasikan pendidikan SD dan prinsipnya ke dalam kehidupan profesional mereka. Ini membolehkan pelajar meningkatkan perhatian mereka terhadap persekitaran dan masyarakat sekeliling mereka.

\section{Pedagogi: Pembelajaran Berasaskan Masalah (Problem-Based Learning, PBL)}

Kaedah dan amalan pengajaran sangat penting untuk dibincangkan secara meluas dalam pendidikan SD. Ini kerana terdapat keperluan untuk mengembangkan kemampuan pelajar untuk berfikir dengan cara baharu dari pandangan dunia yang berbeza. Ianya memerlukan budaya belajar baharu (Gatti et al., 2019). Tambahan pula, dengan struktur kurikulum yang dinamik (Perkins et al., 2018) atau tidak terlalu tertumpu pada aspek teori (Viegas et al. 2016), adalah lebih baik pendekatan pedagogi konstruktism serta strategi pengajaran berkonsepkan pembelajaran melalui perlakuan (learning by doing) diterapkan dalam pendidikan SD (Gatti et al., 2019; Kukeyeva et al., 2014). Salah satu kaedah pembelajaran melalui perlakuan yang dianggap berkaitan dengan pendidikan SD adalah pembelajaran berasaskan masalah (PBL) (Lehtonen et al., 2018; Figueiró \& Raufflet, 2015), dan dilaporkan PBL sangat sesuai digunakan bagi pendidikan SD (Bürgener \& Barth, 2018; Larsson \& Holmberg, 2018; Friman, 2017).

Gatti et al. (2019) menyatakan bahawa PBL mengangkat penyelesaian masalah sebenar yang memerlukan penglibatan pelajar untuk mencari penyelesaian yang konkrit. PBL dikatakan telah berjaya digunakan selama lebih dari tiga puluh tahun dan terus diterima dalam pelbagai disiplin ilmu (Filho et al., 2019; 2020; Savery, 2015). Menurut Wyness dan Dalton (2018), tidak ada satu pun teori pengajaran dan pembelajaran yang dapat mewakili pembelajaran PBL secara berstruktur. Justeru itu, reka bentuk dan kaedah penyampaian PBL dari Wyness dan Dalton (2018) digunakan untuk tujuan penyelidikan ini terutama dalam menakrifkan pengertian PBL:

...students working collaboratively in small groups to solve complex and challenging problems, and encourages a deeper understanding of an issue or problem, through the application of research, prior knowledge, and the production of a 'solution' that may take various forms.

(Wyness \& Dalton, 2018)

Penggunaan pemasalahan secara berulangan secara tidak langsung merubah peranan pensyarah atau tenaga pengajar kepada fasilitator. Ini membolehkan pelajar menyelesaikan masalah dan mengembangkan kemahiran menyelesaikan masalah. Selanjutnya, pelajar belajar "bagaimana belajar" dengan bekerja dalam kumpulan kecil dan terlibat dalam proses penyelesaian masalah dalam pesekitaran mereka. Proses ini merangkumi menganalisis masalah (mengenal pasti dan merungkai masalah), menjalankan penyelidikan bebas dan sumbang saran (mengenal pasti dan memperoleh pengetahuan dan kemahiran yang diperlukan untuk menyelesaikan masalah) dan mengadakan ujian penyelesaian (memeriksa fakta dan kemudian mengoptimumkan penyelesaiannya). Manakala 
terdapat enam ciri-ciri PBL seperti yang disenaraikan dalam Jadual 1.

Jadual 1: Enam ciri-ciri PBL dan huraian setiap satunya

\begin{tabular}{ll}
\hline \multicolumn{1}{c}{ Ciri-ciri PBL } & \multicolumn{1}{c}{ Huraian } \\
\hline Tanggungjawab Pelajar & $\begin{array}{l}\text { Penyelidikan kendiri untuk pelajar mengumpulkan maklumat untuk dibincangkan dalam } \\
\text { kumpulan sebagai satu proses membuat keputusan terhadap pembinaan penyelesaian yang } \\
\text { boleh dilaksanakan. }\end{array}$ \\
& $\begin{array}{l}\text { Simulasi yang melibatkan masalah tidab berstruktur berdasarkan persekitaran sebenar. } \\
\text { Simulasi Masalah }\end{array}$ \\
Integrasi Pembelajaran & PBL dijadikan asas dalam menyatukan maklumat dari pelbagai displin ilmu. \\
Kolaborasi & PBL menyediakan format bagi pembangunan kompetensi dalam amalan bekerjasama. \\
Penilaian & Penilaian harus dilakukan setelah menyelesaikan setiap masalah untuk menyatukan \\
& pengalaman pembelajaran. \\
Aktiviti & Aktiviti yang dilakukan hendaklah mempunyai nilai tambah dalam dunia persekitaran \\
& sebenar. \\
\hline
\end{tabular}

\section{Pendekatan Organisasi: Kaedah Gabungan (Mixed - Method)}

Peralihan IPT ke pendekatan kelestarian terutama dalam pendidikan SD telah melibatkan semua bidang aktiviti. Kelestarian dalam program pengajian yang ditawarkan di IPT bukan hanya tertakluk kepada persoalan apa yang dilakukan di setiap IPT, tetapi juga bagaimana ia dilakukan (Hoover \& Harder, 2015). Hoover dan Harder (2015) menyatakan bahawa bidang pendidikan SD merangkumi bilik darjah yang dinamik, proses membuat keputusan, struktur organisasi, strategi kepemimpinan, inisiatif perancangan strategik dan secara kolektifnya dapat membayangkan masa depan seseorang pelajar.

Dlouhá dan Pospíšilová (2018) menyatakan usaha dalam memastikan pendidikan SD dapat diterapkan dalam kurikulum di IPT dapat dilakukan sama ada melalui pendekatan bawah-atas atau pendekatan atas-bawah. Kedua-dua pendekatan ini dikatakan dapat memastikan kejayaan integrasi pendidikan SD dke dalam kurikulum di IPT. Terdapat beberapa sokongan yang mengatakan pendekatan atas-bawah lebih efektif dalam memastikan pelaksanaan dan amalan pendidikan SD dijayakan di IPT (Brunstein \& King, 2018).

Pengurusan IPT perlu menggunakan pendekatan atas-bawah yang lebih terarah kepada sistem autokratik dengan menggunakan peranan yang telah ditentukan. Walau bagaimanapun, staf akademik memerlukan pendekatan bawah-atas dalam menentukan peranan masing-masing dengan bekerjasama dari semua pihak berkepentingan yang terlibat dengan kurikulum terutama dari aspek pelaksanaan pedagogi. Namun ada berpendapat, kaedah gabungan lebih sesuai kerana ianya dapat menyeimbangkan dua pendekatan yang memungkinkan struktur organisasi yang lebih mantap dan menjadikan sistem pengurusan program pengajian dapat berkembang secara sistematik (Aleixo, Leal, \& Azeiteiro, 2018). 


\section{PEMBINAAN MODEL PENDIDIKAN PEMBANGUNAN LESTARI (SD)}

Model pendidikan SD bagi dibina berdasarkan satu proses yang biasanya digunakan dalam manamana proses penentuan pendidikan SD bagi program pengajian. Bagi kajian ini, pembinaan model pendidikan SD adalah berdasarkan proses berikut:

\section{i) Kenalpasti Komponen}

Komponen yang dikenal pasti dijelaskan secara komprehensif dalam latar belakang dan tinjauan literatur. Ini termasuklah melalui proses mengenal pasti pihak berkepentingan, alatan, pendekatan integrasi, pedagogi dan kaedah perubahan organisasi yang akan digunakan untuk mencapai integrasi optimum model pendidikan SD bagi pelajar program Sarjana Muda Pendidikan (Teknologi Maklumat) di UPSI.

\section{ii) Kenalpasti Kompetensi}

Proses mengenal pasti kompetensi melibatkan kecekapan keberlanjutan yang akan digunakan dengan mengambil kira jenis modul dan hasil pembelajarannya. Selanjutnya, untuk mengenal pasti bagaimana kecekapan kelestarian tersebut dapat memberi manfaat kepada pelajar. Hesselbarth dan Schaltegger (2014) menyatakan bahawa untuk memastikan pembangunan bersifat kesinambungan, kecekapan umum perlu dikenal pasti dahulu. Ini merangkumi kemahiran, motivasi dan kecenderungan afektif untuk menyelesaikan pemasalahan kelestarian dunia sebenar. Kompetensi utama juga digambarkan sebagai multifungsi dan bebas konteks (Hesselbarth \& Schaltegger, 2014). Pengetahuan, kemahiran dan sikap (rujuk Jadual 2) dikatakan menjadi tiga komponen terpenting dalam pendidikan SD (Hesselbarth \& Schaltegger, 2014; Mintz \& Tal, 2014). Suruhanjaya Ekonomi Pertubuhan Bangsa-Bangsa Bersatu untuk Eropah (UNESCO) turut menggambarkan kecekapan dalam pendidikan SD bukan sahaja perlu ada dalam kalangan pelajar tetapi turut diperlukan dalam kalangan pensyarah kerana kedua-duanya saling berkaitan (UNESCO, 2015).

Jadual 2: Tiga komponen dalam pendidikn SD (pengetahuan, kemahiran dan sikap)

\begin{tabular}{|c|c|}
\hline Kategori & Kompetensi \\
\hline Pengetahuan & $\begin{array}{ll}\text { - } & \text { berpengetahuan dalam rangkaian komputer dan pengaturcaraan } \\
\text { - } & \text { berpengetahuan dalam kecekapan tenaga dan sumber tenaga boleh diperbaharui } \\
\text { - } & \text { berpengetahuan dalam grid pintar, bangunan pintar, bangunan hijau dan HEMS }\end{array}$ \\
\hline \multicolumn{2}{|l|}{ Kemahiran } \\
\hline Kemahiran & - $\quad$ berkeupayaan untuk berfikir secara kreatif, refleksi secara kritis dan menyelesaikan masalah \\
\hline Profesional & $\begin{array}{l}\text { - } \quad \text { berkeupayaan untuk memperoleh pengetahuan baharu secara pantas } \\
\text { berkeupayaan untuk memahami konteks ekonomi, persekitaran dan sosial dalam amalan } \\
\text { profesional }\end{array}$ \\
\hline Sumber Manusia & $\begin{array}{l}\text { - } \quad \text { berkeupayaan untuk menyampaikan pandangan secara jelas } \\
\text { - } \quad \text { berkeupayaan untuk menggunakan sumber manusia dan kapasiti lain } \\
\text { - } \quad \text { berkeupayaan untuk mempraktikkan autoriti } \\
\text { - }\end{array}$ \\
\hline
\end{tabular}


Pembinaan Model Pendidikan Pembangunan Lestari untuk Program Pengajian Sarjana Muda Pendidikan Teknologi Maklumat di Universiti Pendidikan Sultan Idris

Received: 21 July 2021; Accepted: 5 September 2021; Published: 6 September 2021

\begin{tabular}{|c|c|}
\hline Kategori & Kompetensi \\
\hline Fungsi yang & - $\quad$ berkeupayaan untuk melaksanakan perundingan secara berkesan \\
\hline Fleksible & - $\quad$ berkeupayaan untuk kordinasi tugas \\
\hline & - $\quad$ berkeupayaan untuk bekerja secara produktif bersama rakan sekerja \\
\hline & - $\quad$ berkeupayaan untuk menunjukkan prestasi yang baik di bawah tekanan \\
\hline Inovasi & - $\quad$ berkeupayaan untuk mempersembahkan produk, menyampaikan idea dan melaporkan laporan \\
\hline & - $\quad$ berkeupayaan untuk menulis laporan, memo dan dokumen \\
\hline \multirow[t]{4}{*}{ Sikap } & $\begin{array}{l}\text { - } \begin{array}{l}\text { kesediaan untuk menganalisis dan membuat keputusan dalam menyelesaikan masalah yang } \\
\text { berkaitan dengan etika }\end{array}\end{array}$ \\
\hline & $\begin{array}{l}\text { - kesediaan untuk mengamalkan sikap beretika, dan mempunyai tanggungjawab terhadap alam dan } \\
\text { masyarakat baik di peringkat tempatan dan global }\end{array}$ \\
\hline & - $\quad$ kesediaan untuk mempersoalkan idea sendiri dan idea orang lain \\
\hline & - $\quad$ kesediaan untuk memperoleh pandangan dunia baharu dalam menangani pembangunan lestari \\
\hline
\end{tabular}

\section{iii) Menyatakan Kompetensi}

Proses menyatakan kompetensi menumpukan kepada proses mengatasi kecekapan kelestarian yang dikenal pasti untuk memberi manfaat kepada pelajar. Selanjutnya, untuk mengenal pasti cara-cara di mana kecekapan kelestarian dapat ditangani dengan baik dengan mengambil kira hasil pembelajaran, seperti yang digambarkan dalam Jadual 3.

Jadual 3: Menyatakan kompetensi berdasarkan pengetahuan, kemahiran dan sikap

\begin{tabular}{|c|c|}
\hline Kategori & Kompetensi \\
\hline Pengetahuan & $\begin{array}{l}\text { Kecekapan ini ditangani oleh: } \\
\text { - } \quad \text { Prinsip kelestarian bersepadu dalam kursus pengaturcaraan dalam mempersiapkan pelajar untuk } \\
\text { kerjaya masa depan mereka dan memberikan pengetahuan, kaedah dan alat untuk merancang } \\
\text { program komputer untuk SD. } \\
\text { Prinsip kelestarian bersepadu dalam kursus rangkaian menyiapkan pelajar untuk kerjaya masa } \\
\text { depan mereka dan memberikan pengetahuan, kaedah dan alat untuk merancang seni bina } \\
\text { rangkaian yang lestari. } \\
\text { Persekitaran pembelajaran terbuka makmal hidup akan memberi pelajar pengetahuan mengenai } \\
\text { kecekapan tenaga, sumber tenaga boleh diperbaharui, grid pintar, bangunan pintar, bangunan hijau } \\
\text { dan HEMS. }\end{array}$ \\
\hline Kemahiran & Kecekapan ini ditangani oleh: \\
\hline $\begin{array}{l}\text { Kemahiran } \\
\text { Profesional }\end{array}$ & $\begin{array}{l}\text { Prinsip kelestarian yang bersepadu dalam rangkaian komputer dan kursus pengaturcaraan } \\
\text { memberikan pelajar kecekapan dalam pemikiran kreatif dan refleksi kritis. } \\
\text { Prinsip kelestarian bersepadu merangkumi maklumat mengenai ekonomi, persekitaran dan } \\
\text { konteks sosial. }\end{array}$ \\
\hline Sumber Manusia & $\begin{array}{l}\text { - Kerja kumpulan dapat digunakan untuk mengembangkan kecekapan. } \\
\text { - Kehidupan sebenar dan contoh praktikal mendedahkan pelajar kepada amalan yang berkaitan } \\
\text { dengan pengurusan sumber manusia. } \\
\text { Pelajar juga akan dinilai berdasarkan tingkah laku mereka dalam kerja berpasukan dan interaksi } \\
\text { dengan orang lain. }\end{array}$ \\
\hline Fungsi yang & - Students will also be assessed based on their behavior in teamwork, and interaction with others \\
\hline Fleksible & $\begin{array}{l}\text { - } \quad \text { Kerja kumpulan dapat digunakan untuk mengembangkan kecekapan. } \\
\text { Pelajar juga akan dinilai berdasarkan tingkah laku mereka dalam kerja berpasukan dan interaksi } \\
\text { dengan orang lain. }\end{array}$ \\
\hline Inovasi & $\begin{array}{l}\text { - Projek membolehkan pelajar mengaplikasikan pengetahuan yang mereka perolehi dalam } \\
\text { pembangunan penyelesaian kelestarian yang inovatif. }\end{array}$ \\
\hline
\end{tabular}




\begin{tabular}{llc}
\hline Kategori & Kompetensi \\
\hline & $\bullet$ & Pelajar akan diminta untuk membentangkan hasil projek secara lisan dan laporan bertulis. \\
\hline Sikap & Kecekapan ini ditangani oleh: \\
& $\bullet$ & Kerja yang berkaitan dengan SD memberi pelajar set pemikiran kelestarian yang diperlukan. \\
& $\bullet$ & Pelajar juga akan dinilai berdasarkan kehadiran, kesetiaan, kejujuran, dan sikap mereka. \\
\hline
\end{tabular}

\section{iv) Analisis Kurikulum}

Analisis kurikulum dilakukan untuk mengenal pasti alat penilaian terbaik untuk digunakan untuk analisis kurikulum yang ingin disatukan dalam pendidikan SD. Penilaian kurikulum dapat dihasilkan tanpa mengira mengapa IPT memilih untuk melaksanakan pendidilkan SD, penilaian kurikulum dapat ditawarkan kepada pihk berkepentingan sebagai titik permulaan perubahan (Stough et al., 2018).

Tambahan pula, walaupun terdapat sebilangan alat penilaian yang tersedia untuk penyelidik, alatanyang dikenali sebagai Sustainability Tool for Assessing Universities' Curricula Holistically (STAUNCH (C) sangat sesuai digunakan untuk kajian ini. Ini kerana penilaiannya memberi tumpuan khusus pada kurikulum dan bertujuan untuk membantu universiti secara holistik dan sistematik untuk menilai sumbangan kurikulum mereka kepada SD. Manakala, alat penilaian seperti AISHE, GASU dan STARS hanya memberikan gambaran keseluruhan aktiviti IPT sahaja dan hanya untuk meningkatkan kelestarian operasi kampus (Filho et al., 2019; Gouvea, Kapelianis, \& Kassicieh, 2018; Aktas et al., 2015; Lozano \& Lozano, 2014).

\section{v) Intrgrasi Kurikulum}

Integrasi kurikulum dilaksanakan untuk mengenal pasti proses integrasi optimum yang bergantung pada pendekatan integrasi yang ingin digunakan ketika mengintegrasikan atau menerapkan pendidikan SD ke dalam kurikulum. Selanjutnya, pemahaman mengenai hasil pembelajaran modul adalah penting untuk proses pelaksanaan integrasi ini dapat dijayakan.

Dalam konteks penyelidikan ini, tumpuan diberikan kepada tiga bahagian utama dalam pendidikan SD iaitu kelestarian, Teknologi Maklumat, dan makmal kehidupan (living lab). Selanjutnya, ketiganya dibahagikan lagi kepada komponen penting untuk setiap bidang pengetahuan, seperti yang dilihat pada Rajah 3. Tambahan pula, kecekapan tenaga dijadikan komponen pendidikan SD utama untuk memberi peluang kepada pelajar untuk belajar mengenai sumber tenaga yang boleh diperbaharui. Ini dibantu oleh penggunaan makmal kehidupan yang seterusnya memberi pengetahuan kepada pelajar mengenai grid pintar, bangunan pintar dan Home Energy Management System (HEMS). 

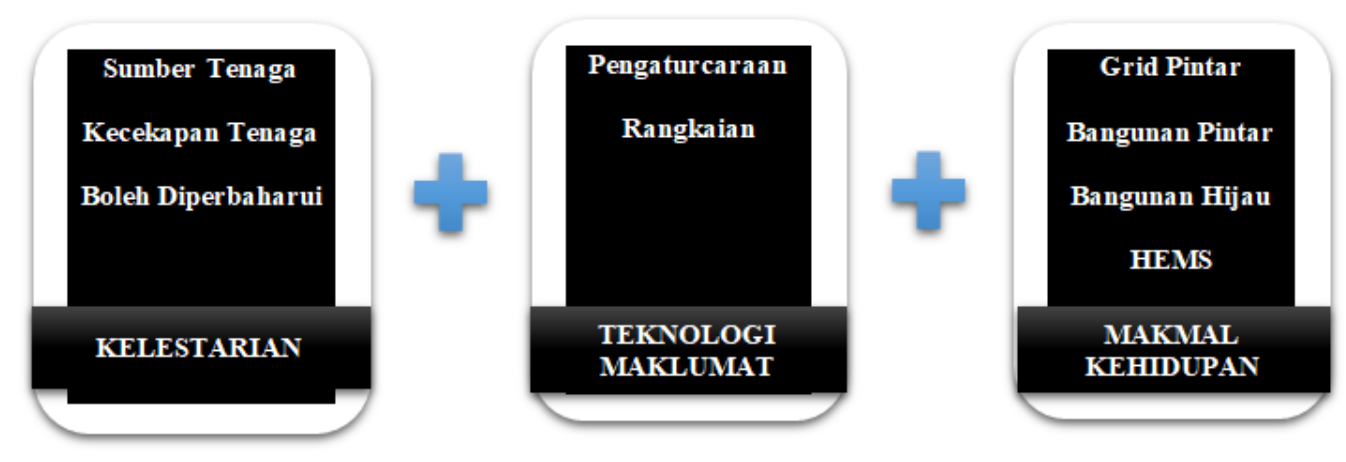

Rajah 1: Integrasi tiga bahagian utama pendidikan SD

Rajah 1 menunjukkan blok merah yang berkaitan dengan kelestarian dalam konteks kajian ini yang merujuk kepada kecekapan tenaga dan sumber tenaga yang dapat diperbaharui. Blok kuning pula berkaitan dengan program pengajian Sarjana Muda Pendidikan Teknologi Maklumat (information technology@ IT) yang terlibat dalam konteks kajian ini dengan menumpukan kepada dua modul khusus yang dipilih iaitu pengaturcaraan dan rangkaian. Blok hijau berkaitan dengan makmal kehidupan yang mana dalam konteks kajian ini ianya merujuk kepada grid pintar, bangunan pintar, bangunan hijau dan HEMS.

Rajah 2 pula menunjukkan secara hierarki sumbangan SD yang berkaitan dengan pemasalahan alam sekitar, tenaga dan sosial yang disatukan ke dalam kurikulum. Sumbangan SD yang disebutkan dapat dirumuskan dengan bantuan pendidikan SD seperti yang dijelaskan untuk model ini. Dengan penggunaan kunci yang disediakan, struktur hierarki dapat dikaitkan dengan dengan tiga bidang utama yang ditunjukkan dalam Rajah 1 sebelum ini. 


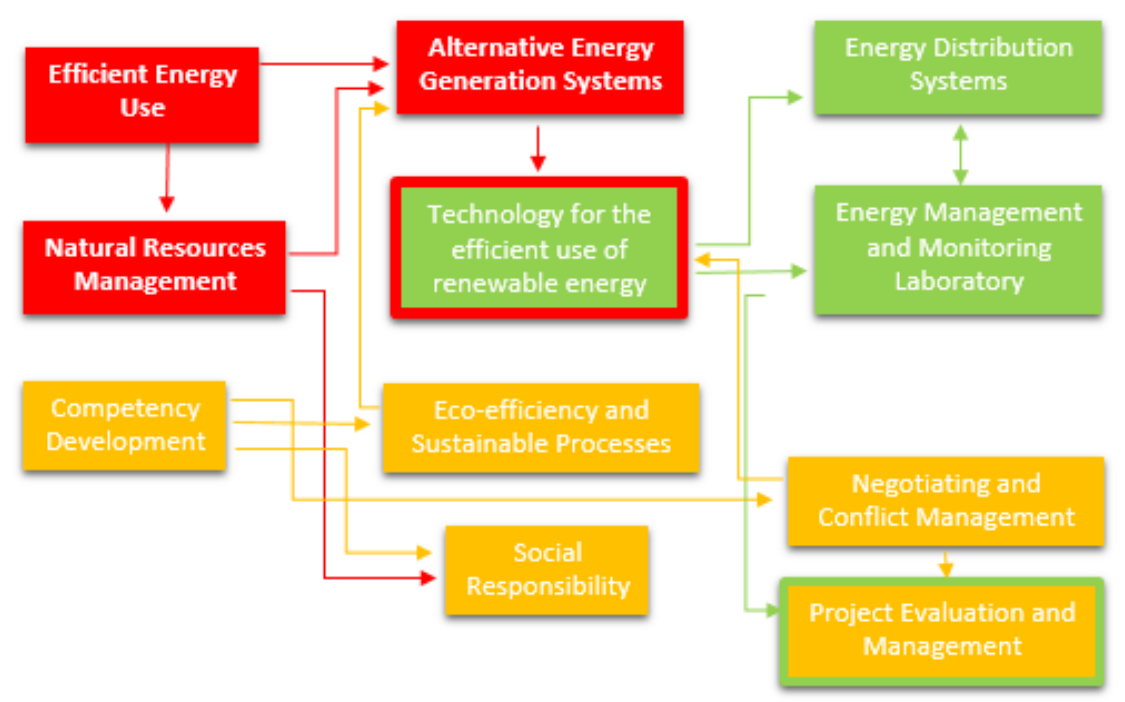

Rajah 2: Struktur hirarki integrasi sumbangan SD ke dalam kurikulum.

Dengan menggunakan hasil pembelajaran kursus yang telah ditetapkan, proses integrasikan SD ke dalam kurikulum lebih mudah ditetapkan. Namun, penting untuk diperhatikan bahawa tidak semua hasil pembelajaran yang disediakan dalam dokumen pro forma atau silibus digunakan. Hanya hasil pembelajaran yang sesuai dengan lima kriteria inklusif yang ditetapkan sahaja yang digunakan. Ini memungkinkan penyusunan semula kurikulum kursus yang ada tanpa memerlukan reka bentuk dan pengembangan kurikulum baharu yang lengkap.

Lima kriteria inklusif adalah seperti berikut:

i. Hasil pembelajaran yang memungkinkan penggunaan mudah oleh kordinator kursus.

ii. Hasil pembelajaran yang dapat membantu menangani pendidikan SD yang dikembangkan.

iii. Hasil pembelajaran yang dapat diterima pakai sebagai persediaan makmal kehidupan.

iv. Hasil pembelajaran yang memungkinkan integrasi SD antara disiplin.

v. Hasil pembelajaran yang boleh diajar menggunakan pedagogi PBL.

\section{v) Menilai Model}

Proses menilai model dapat dilakukan melalui penilaian formatif dan sumatif model. Ia adalah penting untuk diperhatikan sama ada kelestarian dapat memastikan peningkatan secara berterusan. Penilaian formatif dijalankan semamasa pengajaran teknologi dan kelestarian untuk mengesan penguasaan dan kemajuan pelajar untuk membaiki kelemahannya dengan serta-merta. Penilai 
sumatif pula merujuk kepada ujian formal selepas mengajar beberapa unit pembelajaran tentang teknologi dan kelestarian bagi mengesan pencapaian pelajar melalui gred yang didapati daripada ujian kertas-pensel dan lisan. Oleh itu, pindaan model tidak dapat dipisahkan kerana pendidikan terus bergabung dengan teknologi dan pendidikan tenaga yang terkini. Pada akhirnya, model pendidikan SD bagi program pengajian Sarjana Muda Pendidikan (Teknologi Maklumat) digambarkan dalam Rajah 3.

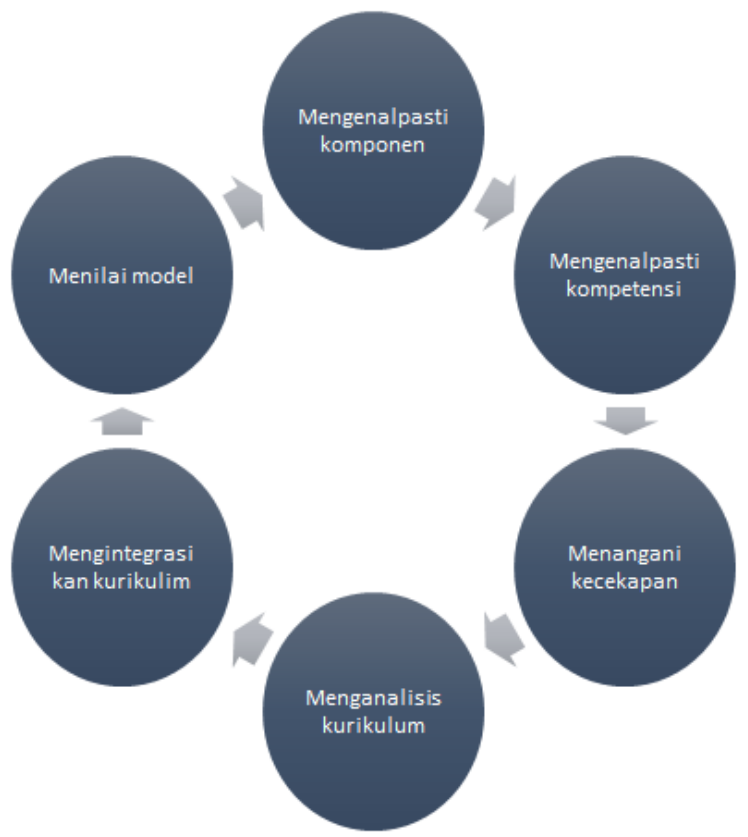

Rajah 3: Model Pendidikan SD bagi Sarjana Muda Pendidikan (Teknologi Maklumat).

\section{RUMUSAN}

Artikel ini melaporkan pembinaan model pendidikan SD bagi program pengajian Sarjana Muda Pendidikan (Teknologi Maklumat) di UPSI. Secara umumnya, ia memberikan gambaran jelas mengenai model dan semua aspek yang diperlukan untuk mengintegrasikan model tersebut ke dalam kurikulum. Selanjutnya, ianya mengenal pasti pendidikan SD dan menunjukkan cara-cara bagaimana pendidikan SD dapat disatukan ke dalam kurikulum program pengajian yang ada. Dapat disimpulkan bahawa pendidikan SD masih di peringkat awal lebih-lebih lagi dalam konteks kurikulum dalam bidang komputeran. Ini kerana sebahagian besar penyelidikan semasa mengenai topik pendidikan SD berpusat di sekitar dua bidang pengajian yang menonjol iaitu kejuruteraan dan pengurusan perniagaan. 


\section{RUJUKAN}

Adams, R., Martin, S., \& Boom, K. (2018). University culture and sustainability: Designing and implementing an enabling framework. Journal of Cleaner Production, 171, 434-445. https://doi.org/10.1016/j.jclepro.2017.10.032

Akins, E. E., Giddens, E., Glassmeyer, D., Gruss, A., Hedden, M. K., Slinger-Friedman, V., \& Weand, M. (2019). Sustainability education and organizational change: A critical case study of barriers and change drivers at a higher education institution. Sustainability, 11(2), 501. https://doi.org/10.3390/su11020501

Aktas, C. B., Whelan, R., Stoffer, H., Todd, E., \& Kern, C. L. (2015). Developing a university-wide course on sustainability: A critical evaluation of planning and implementation. Journal of Cleaner Production, 106, 216221. https://doi.org/10.1016/j.jclepro.2014.11.037

Aleixo, A. M., Leal, S., \& Azeiteiro, U. M. (2018). Conceptualization of sustainable higher education institutions, roles, barriers, and challenges for sustainability: An exploratory study in Portugal. Journal of Cleaner Production, 172, 1664-1673. https://doi.org/10.1016/j.jclepro.2016.11.010

Brunstein, J., \& King, J. (2018). Organizing reflection to address collective dilemmas: Engaging students and professors with sustainable development in higher education. Journal of Cleaner Production, 203, 153-163. https://doi.org/10.1016/j.jclepro.2018.08.136

Bürgener, L., \& Barth, M. (2018). Sustainability competencies in teacher education: Making teacher education count in everyday school practice. Journal of Cleaner Production, 174, 821-826. https://doi.org/10.1016/j.jclepro.2017.10.263

Casarejos, F., Gustavson, L. M., \& Frota, M. N. (2017). Higher education institutions in the United States: Commitment and coherency to sustainability vis-à-vis dimensions of the institutional environment. Journal of Cleaner Production, 159, 74-84. https://doi.org/10.1016/j.jclepro.2017.05.034

Ciriminna, R., Meneguzzo, F., Pecoraino, M., \& Pagliaro, M. (2016). Rethinking solar energy education on the dawn of the solar economy. Renewable and Sustainable Energy Reviews, 63, 13-18. https://doi.org/10.1016/j.rser.2016.05.008

Desha, C., Robinson, D., \& Sproul, A. (2015). Working in partnership to develop engineering capability in energy efficiency. Journal of Cleaner Production, 106, 283-291. https://doi.org/10.1016/j.jclepro.2014.03.099

Dlouhá, J., \& Pospíšilová, M. (2018). Education for Sustainable Development Goals in public debate: The importance of participatory research in reflecting and supporting the consultation process in developing a vision for Czech education. Journal of Cleaner Production, 172, 4314-4327. https://doi.org/10.1016/j.jclepro.2017.06.145

Figueiró, P. S., \& Raufflet, E. (2015). Sustainability in higher education: A systematic review with focus on management education. Journal of Cleaner Production, 106, 22-33. https://doi.org/10.1016/j.jclepro.2015.04.118

Filho, W. L., Doni, F., Vargas, V. R., Wall, T., Hindley, A., Rayman-Bacchus, L., . . . Avila, L. V. (2019). The integration of social responsibility and sustainability in practice: Exploring attitudes and practices in higher education institutions. Journal of Cleaner Production, 152-166. https://doi.org/10.1016/j.jclepro.2019.02.139

Flammini, A., Pasetti, M., Rinaldi, S., Bellagente, P., Ciribini, A. C., Tagliabue, L. C., ... \& Pedrazzi, G. (2018, October). A living lab and testing infrastructure for the development of innovative smart energy solutions: the eLUX Laboratory of the University of Brescia. In 2018 AEIT International Annual Conference (pp. 1-6). IEEE. https://doi.org/10.1016/j.jclepro.2019.02.139

Friman, H. (2017). New trends in the higher education: Renewable energy at the Faculty of Electrical Engineering. Energy Procedia, 115, 18-28. https://doi.org/10.1016/j.egypro.2017.05.003 
Gatti, L., Ulrich, M., \& Seele, P. (2019). Education for sustainable development through business simulation games: An exploratory study of sustainability gamification and its effects on students learning outcomes. Journal of Cleaner Production, 207, 667-678. https://doi.org/10.1016/j.jclepro.2018.09.130

Gouvea, R., Kapelianis, D., \& Kassicieh, S. (2018). Assessing the nexus of sustainability and information \& communications technology. Technological Forecasting and Social Change, 130, 39-44. https://doi.org/10.1016/j.techfore.2017.07.023

Hess, D. J., \& Collins, B. M. (2018). Climate change and higher education: Assessing factors that affect curriculum requirements. Journal of Cleaner Production, 170, 1451-1458. https://doi.org/10.1016/j.jclepro.2017.09.215

Hesselbarth, C., \& Schaltegger, S. (2014). Educating change agents for sustainability - learnings from the first sustainability management master of business administration. Journal of Cleaner Production, 62, 24-36. https://doi.org/10.1016/j.jclepro.2013.03.042

Hoover, E., \& Harder, M. K. (2015). What lies beneath the surface? The hidden complexities of organizational change for sustainability in higher education. Journal of Cleaner Production, 106, 175-188. https://doi.org/10.1016/j.jclepro.2014.01.081

Hossain, M., Leminen, S., \& Westerlund, M. (2019). A systematic review of living lab literature. Journal of Cleaner Production, 213, 976-988. https://doi.org/10.1016/j.jclepro.2018.12.257

Jahn, M., Patti, E., \& Acquaviva, A. (2013, May). Smart energy efficient buildings-A Living Lab approach. Dalam SMARTGREENS (pp. 171-176).

Klimova, A., \& Rondeau, E. (2017). Education for cleaner production in Information and Communication Technologies $\quad$ curriculum. IFAC-PapersOnLine, $\quad$ 50(1), 12931-12937. https://doi.org/10.1016/j.ifacol.2017.08.1792

Kukeyeva, F., Delovarova, L., Ormysheva, T., \& Davar, A. (2014). Higher education and sustainable development in Kazakhstan. Procedia - $\quad$ Social and Behavioral $\quad$ Sciences, $\quad 122, \quad 152$ 156.https://doi.org/10.1016/j.sbspro.2014.01.1318

Larsson, J., \& Holmberg, J. (2018). Learning while creating value for sustainability transitions: The case of Challenge $\mathrm{Lab}$ at Chalmers University of Technology. Journal of Cleaner Production, 172, 4411-4420. https://doi.org/10.1016/j.jclepro.2017.03.072

Leal Filho, W., Doni, F., Vargas, V. R., Wall, T., Hindley, A., Rayman-Bacchus, L., ... \& Avila, L. V. (2019). The integration of social responsibility and sustainability in practice: exploring attitudes and practices in Higher Education Institutions. Journal of Cleaner Production, 220, 152-166. https://doi.org/10.1016/j.jclepro.2019.02.139

Lehtonen, A., Salonen, A., Cantell, H., \& Riuttanen, L. (2018). A pedagogy of interconnectedness for encountering climate change as a wicked sustainability problem. Journal of Cleaner Production, 199, 860-867. https://doi.org/10.1016/j.jclepro.2018.07.186

Li, N., Chan, D., Mao, Q., Hsu, K., \& Fu, Z. (2018). Urban sustainability education: Challenges and pedagogical experiments. Habitat International, 71, 70-80. https://doi.org/10.1016/j.habitatint.2017.11.012

Lozano, F. J., \& Lozano, R. (2014). Developing the curriculum for a new Bachelors degree in Engineering for Sustainable Development. Journal of Cleaner Production, $\quad 64, \quad 136-146$. https://doi.org/10.1016/j.jclepro.2013.08.022 
Masseck, T. (2017). Living Labs in architecture as innovation arenas within higher education institutions. Energy Procedia, 115, 383-389. https://doi.org/10.1016/j.egypro.2017.05.035

Mintz, K., \& Tal, T. (2014). Sustainability in higher education courses: Multiple learning outcomes. Studies in Educational Evaluation, 41, 113-123. https://doi.org/10.1016/j.stueduc.2013.11.003

Nilsson, A., Wester, M., Lazarevic, D., \& Brandt, N. (2018). Smart homes, home energy management systems and real-time feedback: lessons for changing energy consumption behavior from a Swedish field study. Energy and Buildings, 179. 15-25. https://doi.org/10.1016/j.enbuild.2018.08.026

Nishimura, É. K., \& Malheiros, T. F. (2018). Inclusion of Sustainability in Higher Education Institutions: A Comparative Study of São Carlos School of Engineering-University of São Paulo and the Leuphana University of Lüneburg. In Towards Green Campus Operations (pp. 409-426). Springer, Cham.

Nižetić, S., Djilali, N., Papadopoulos, A., \& Rodrigues, J. J. (2019). Smart technologies for promotion of energy efficiency, utilization of sustainable resources and waste management. Journal of Cleaner Production. 231, 565591. https://doi.org/10.1016/j.jclepro.2019.04.397

Nowotny, J., Dodson, J., Fiechter, S., Gür, T. M., Kennedy, B., Macyk, W., . . Rahman, K. A. (2018). Towards global sustainability: Education on environmentally clean energy technologies. Renewable and Sustainable Energy Reviews, 81, 2541-2551. https://doi.org/10.1016/j.rser.2017.06.060

Paletta, A., Fava, F., Ubertini, F., Bastioli, C., Gregori, G., Camera, F. L., \& Douvan, A. R. (2019). Universities, industries and sustainable development: Outcomes of the 2017 G7 Environment Ministerial Meeting. Sustainable Production and Consumption, 19, 1-10. https://doi.org/10.1016/j.spc.2019.02.008

Pattinson, C. (2017). ICT and green sustainability research and teaching. IFAC-PapersOnLine, 50(1), 12938-12943. https://doi.org/10.1016/j.ifacol.2017.08.1794

Perkins, K. M., Munguia, N., Moure-Eraso, R., Delakowitz, B., Giannetti, B. F., Liu, G., . . . Velazquez, L. (2018). International perspectives on the pedagogy climate change. Journal of Cleaner Production, 200, 1043-1052. https://doi.org/10.1016/j.jclepro.2018.07.296

Purvis, B., Mao, Y., \& Robinson, D. (2019). Three pillars of sustainability: In search of conceptual origins. Sustainability Science, 14(3), 681-695. https://doi.org/10.1007/s11625-018-0627-5

Ramos, T. B., Montaño, M., Melo, J. J., Souza, M. P., Lemos, C. C., Domingues, A. R., \& Polido, A. (2015). Strategic environmental assessment in higher education: Portuguese and Brazilian cases. Journal of Cleaner Production, 106, 222-228. https://doi.org/10.1016/j.jclepro.2014.12.088

Raoufi, K., Park, K., Khan, M. T., Haapala, K. R., Psenka, C. E., Jackson, K. L., . . Kim, K. (2019). A cyberlearning platform for enhancing undergraduate engineering education in sustainable product design. Journal of Cleaner Production, 211, 730-741. https://doi.org/10.1016/j.jclepro.2018.11.085

Romanach, L., Leviston, Z., Jeanneret, T., \& Gardner, J. (2017). Low-carbon homes, thermal comfort and household practices: Uplifting the energy-efficiency discourse. Energy Procedia, 121, 238-245. https://doi.org/10.1016/j.egypro.2017.08.023

Sahakian, M., \& Seyfang, G. (2018). A sustainable consumption teaching review: From building competencies to transformative learning. Journal of Cleaner Production, $198, \quad 231-241$. https://doi.org/10.1016/j.jclepro.2018.06.238

Savery, J. R. (2015). Overview of problem-based learning: Definitions and distinctions. Essential readings in problembased learning: Exploring and extending the legacy of Howard S. Barrows, 9(2), 5-15. 
Sidiropoulos, E. (2014). Education for sustainability in business education programs: A question of value. Journal of Cleaner Production, 85, 472-487. https://doi.org/10.1016/j.jclepro.2013.10.040

Sidiropoulos, E. (2018). The personal context of student learning for sustainability: Results of a multi-university research study. Journal of Cleaner Production, 181, 537-554. https://doi.org/10.1016/j.jclepro.2018.01.083

Staniškis, J. K., \& Katiliūtè, E. (2016). Complex evaluation of sustainability in engineering education: Case \& analysis. Journal of Cleaner Production, 120, 13-20. https://doi.org/10.1016/j.jclepro.2015.09.086

Stough, T., Ceulemans, K., Lambrechts, W., \& Cappuyns, V. (2018). Assessing sustainability in higher education curricula: A critical reflection on validity issues. Journal of Cleaner Production, 172, 4456-4466. https://doi.org/10.1016/j.jclepro.2017.02.017

Symaco, L. P., \& Tee, M. Y. (2019). Social responsibility and engagement in higher education: Case of the ASEAN. International Journal of Educational Development, $\quad 66, \quad 184-192$. https://doi.org/10.1016/j.ijedudev.2018.10.001

Torre, D., Procaccianti, G., Fucci, D., Lutovac, S., \& Scanniello, G. (2017). On the presence of green and sustainable software engineering in higher education curricula. 2017 IEEE/ACM 1st International Workshop on Software Engineering Curricula for Millennials (SECM). doi:10.1109/secm.2017.4

Trechsel, L. J., Zimmermann, A. B., Graf, D., Herweg, K., Lundsgaard-Hansen, L., Rufer, L., . . Wastl-Walter, D. (2018). Mainstreaming education for sustainable development at a Swiss University: Navigating the traps of institutionalization. Higher Education Policy, 31(4), 471-490. https://doi.org/10.1057/s41307-018-0102-z

UNESCO (2015). Sustainable Development Goals. https://en.unesco.org/sustainabledevelopmentgoals

Viegas, C. V., Bond, A. J., Vaz, C. R., Borchardt, M., Pereira, G. M., Selig, P. M., \& Varvakis, G. (2016). Critical attributes of sustainability in higher education: A categorisation from literature review. Journal of Cleaner Production, 126, 260-276. https://doi.org/10.1016/j.jclepro.2016.02.106

Wals, A. E. (2014). Sustainability in higher education in the context of the UN DESD: A review of learning and institutionalization processes. Journal of Cleaner Production, $\quad 62, \quad 8-15$. https://doi.org/10.1016/j.jclepro.2013.06.007

Washington-Ottombre, C., Washington, G. L., \& Newman, J. (2018). Campus sustainability in the US: Environmental management and social change since 1970. Journal of Cleaner Production, 196, 564-575. https://doi.org/10.1016/j.jaccedu.2018.09.001

Wyness, L., \& Dalton, F. (2018). The value of problem-based learning in learning for sustainability: Undergraduate accounting student perspectives. Journal of Accounting Education, $45, \quad 1-19$. https://doi.org/10.1016/j.jaccedu.2018.09.001

Zhou, B., Li, W., Chan, K. W., Cao, Y., Kuang, Y., Liu, X., \& Wang, X. (2016). Smart home energy management systems: Concept, configurations, and scheduling strategies. Renewable and Sustainable Energy Reviews, 61, 30-40. https://doi.org/10.1016/j.rser.2016.03.047 